\title{
Core Competency and Performance Management in Selected Private Secondary Schools in Port Harcourt, Nigeria
}

\author{
Ngozi Nzewi \\ Department of Business Administration, P.M.B 5025, Nnamdi Azikiwe University, Awka, \\ Nigeria \\ E-mail: hn.nzewi@unizik.edu.ng
}

Ebele Onwuka

Department of Business Administration, P.M.B 5025, Nnamdi Azikiwe University, Awka, Nigeria

E-mail: em.onwuka@unizik.edu.ng

Godwin Bupo (Corresponding Author)

Department of Vocational Education, P.M.B 5025, Nnamdi Azikiwe University, Awka, Nigeria

E-mail: godwin.bupo@ust.edu.ng

Received: December 18, 2017 Accepted: December 28, 2017 Published: March 20, 2018

doi:10.5296/bms.v9i1.12852ＵRL: https://doi.org/10.5296/bms.v9i1.12852

\begin{abstract}
The study sought to determine how core competencies are employed during the performance management process of the selected private secondary schools in Port Harcourt. The need to ascertain whether these organizations employ their core competencies during their performance evaluation process led to this study. Survey research design was employed for the study. Two research questions were raised and one hypothesis was tested at 0.05 level of significance. The population of the study was 210 workers in the two private secondary
\end{abstract}




\section{Macrothink}

schools that were selected for the study (Graceland International Secondary School and Blessed Children Academy High School). The entire population was used for the study. Structured questionnaire was used for data collection. The reliability of the instrument, tested through split-half method, were 0.61 and 0.71 for sections B and C respectively. Mean and Standard deviation were used to answer the research questions while Z-test was used to test the hypothesis. The findings of the study revealed that the respondents agreed that employees' performance was measured by the outcomes of their effort, by the behavioral characteristics that led to those outcomes, and not by how closely related they were with top management or by how long they have been working in the organization. Based on the findings, it was recommended among others, that management of private secondary schools in Port Harcourt should lay more emphasis on behavioral competences not just on only the outcome of employees' effort.

Keywords: core competency, technical competence, behavioural competence, performance management, private secondary schools 


\section{Introduction}

Performance management is a very important aspect of the strategic management process of any organization. It goes beyond appraising the worker to determine his strengths and weaknesses. Performance management is a continuous process of identifying, measuring and developing performance in organizations by linking each individual's performance and objectives to the organization's overall mission and goals (Aguinis, 2011). Workers' performances are measured on a daily basis, although a formal performance appraisal can take place once or twice a year (Nwachukwu, 2009). Workers are appraised in order to gather information for promotion, demotion, transfer, pay increase, training and development and discharge. This helps in the evaluation of the workers' performance over time and to ascertain if the organizational goals are being met. Performance management is therefore, a continuous process of measuring workers' activities and behavior as against the goals of the organization. This helps to immediately improve the workers' performance by correcting areas of deficiency rather than waiting for the appraisal time.

As important as the performance management process is, it can be ruined if the right standards are not used. Many private organizations seem not to have a structured standard by which workers' performances are measured. Performance management procedure should be based on some clear-cut policies that will allow for objectivity and neutrality. To ensure that performance management practices are standardized, private organizations need to use their core competencies to evaluate workers' performances. This study seeks to determine how two selected private secondary schools in Port Harcourt apply their core competencies in the performance management process.

\section{Theoretical Framework}

This study is premised on Frederick Taylor's scientific management theory. Frederick Taylor, according to Stoner, Freeman and Gilbert (2008), generated four principles upon which the management of organizations should follow. These include: The development of a true science of management; The scientific selection of workers; The scientific education and training of workers and; Intimate, friendly cooperation between management and labour. Taylor was of the view that workers performance should be objectively determined in a scientific manner. He emphasized that workers should be paid as they work (the differential rate system), i.e., the more effective and efficient the workers work, the more pay they receive and vice versa. This theory relates to this study in that the study examines how the performance of staff of private secondary schools in Port Harcourt are measured. It examined whether core competencies of the organization are employed during the performance management process or whether the process is subjectively done.

\subsection{Literature Review}

Competencies refer to a person's abilities, knowledge and skills that can give him competitive advantage above others. It is that quality (behavioural or technical) that a person possesses to 
be able to carry out a particular job junction. Takey and de Carvalho (2015) defined individual competence as the ability to mobilize, integrate and transfer knowledge, skills and resources to reach or surpass the configured performance in work assignments, adding economic and social value to the organization and to the individual. Cole (2002) defined competence to mean a person's ability to perform a task to an externally-agreed standard, whether set by the organization or some third party. Becker, Huselid and Ulrich (cited by Sunil, 2006) defined the competence of an individual as the knowledge, skills, abilities, or personality characteristics that directly influence one's performance. The issue of workers' performance is of primary concern to business organizations as it can be of competitive advantage to them in the fast-evolving business world. A worker's performance should be assessed based, not only on the outcome of his efforts but also, on his or her competence (behavioral attitudes and skills). According to Seo, Park, and Lee (2016), competence is the continuous tendency that allows the prediction of an individual's behavior in various situations and includes motive, trait, self-concept, skill, and knowledge.

Core competencies refer to those qualities that organizations uphold as distinctive qualities that give them competitive advantage over others. These are values that give an organization its uniqueness and are embedded in the Vision and Mission statements of the organization to which all employees are supposed to conform to and uphold. Boguslauskas and Kvedaraviciene (2009) pointed out that core competencies provide sustainable competitive advantage for a company which makes the company to operate uniquely and successfully in a common environment (i.e. an environment filled with competitors). As posited by Moore (2002), any behavior which can raise the stock price and everything else in a company can be said to a core competence while Kogut and Kulatilaka (2001) see core competence as those capabilities that permit the firm to make the best response to market opportunities. A core competency is best described as a set of skills and capabilities that create unique value in the market place which provide long term differentiation of an organization (Koloupolus \& Rollof, 2006). A core competence is a deep proficiency that enables a company to deliver unique value to customers. It embodies an organization's collective learning, particularly of how to coordinate diverse production skills and integrate multiple technologies (Rigby \& Bilodeau, 2007). One can conclude from the various definitions that an organization's core competencies are those traits, values, skills, knowledge, qualities and aptitudes that makes the organization uniquely different from others.

There are two types of competencies generally speaking: behavioural and technical competencies. Behavioural competencies, sometimes referred to as soft skills, are those types of behaviour or behavioural expectations required to bring out needed performance. They refer to behavioral patterns in areas like team work, communication, leadership and decision making. In order to assess a person's behavioral competency, criterion-referenced assessment is used. Armstrong (2006) defined criterion referencing as the process of analyzing the key aspects of behavior that differentiate between effective and less effective performance. (Boyatzis, 1982) who is a leading contributor to the concept of competency, carried out studies and discovered that a range of factors affect performance. According to Boyatzis, 
competency refers to the capacity that exists in a person that leads to behavior that meets the job demands within the parameters of the organizational environment and that, in turn, brings about desired results. The competency clusters discovered by Boyatzis include: goal and action management; leadership; human resources management; and directing subordinates.

On the other hand, technical competencies refer to what a person has to know and be able to do in order to carry out his/her job functions. These competencies can be related to generic job roles or specific/individual roles. In this line, competency can be said to be a work-related concept which refers to areas of work at which a person is competent (Woodruffe in Armstrong, 2006). Technical competencies deal with the skills required for specific activities and tasks. That is, for a worker to perform certain tasks, he/she must have undergone the necessary training required for the task. Such training, which can be gotten from a formal schooling or by apprenticeship, provides the person with the skills needed to function in the required capacity. Hayton and Kelley (2006) posited that employees develop technical competencies "through education and training by sharing experiences with others, while learning by doing, and when learning vicariously by observing others' trials and errors” pg 412. Teaching and non-teaching staff of secondary schools ought to have the technical competence to handle their duties. Teachers should have studied education and the pedagogical process while other administrative staff should be technically qualified to perform their job duties.

According to Armstrong (2006), other competencies that should be used in the performance management process include team orientation, communication ability, people management, problem-solving ability, technical skills, decision making, planning and organizing ability, result orientation, leadership ability, student-friendly, initiative and interpersonal skills.

\subsection{Statement of the Problem}

As important as the performance management process is, it can be ruined if the right standards are not used. Many private secondary schools seem not to have a structured standard by which workers' performances are measured. There appears to be lack of the use of core competencies in the performance management process of some private schools in Port Harcourt who do not seem to consider soft skills of their workers during the appraisal process. There appears to be subjectivity in the performance management process of private secondary schools. More so, there is no research, known to the researchers, that covers how core competencies are used in the performance management process of private secondary schools in Port Harcourt, hence this study.

\subsection{Purpose of the Study}

The objective of this study was to ascertain the core competencies used during performance management processes in selected private secondary schools in Port Harcourt. Specifically, the study sought to:

1. Determine how employees' performances are measured in the selected private secondary 
schools in Port Harcourt.

2. Determine how obligatory private secondary schools in Port Harcourt consider their core competencies during performance appraisals and performance management.

\subsection{Research Questions}

The following research questions were raised to guide the study.

1. How are employees' performances measured in the selected private secondary schools in Port Harcourt?

2. How obligatory do the selected private secondary schools in Port Harcourt consider their core competencies during performance appraisals and performance management?

\subsection{Hypothesis}

Male and female staff of the selected private secondary schools in Port Harcourt do not significantly differ in their mean ratings as to how obligatory their core competences are considered during performance appraisals and performance management.

\section{Method}

The survey research designed was employed for the study. The population of the study was made up of 210 employees of two private secondary schools selected for the study. The two schools are Graceland International Secondary School, Port Harcourt (111 staff) and Blessed Children Academy High School (99 Staff). The entire population was used for the study hence there was no need for sample and sampling technique. The instrument used for data collection was a questionnaire titled, Core Competency and Performance Management in Private Organizations Questions (CCAPEMIPOQ), which was designed by the researchers from literature. The questionnaire had 3 sections. The first section contains demographic data which was to elicit information of respondents' gender and school. In the second section of the questionnaire, the respondents were required to say how performances of employees in their school were measured. The third part of the questionnaire, had a list of 12 competencies to which the respondents were to say how obligatory they were employed in the performance appraisal and management process of their school. The reliability of the instrument was tested using split-half method. The reliability coefficients of 0.61 and 0.71 for sections B and C were gotten with the spearman rank order. The instrument was administered to the respondents with the help of two research assistance who were trained for the purpose. Proper approval was gotten from the management of the schools before the administration of the questionnaire was done. Mean and Standard Deviation were used to analyze the research questions. Z-test was used in analyzing the hypothesis. The decision rule was to reject the hypothesis if the Z-calculated is greater than the Z-critical and to accept the hypothesis if the $\mathrm{Z}$-calculated is less than the Z-critical value. 


\section{Results}

Two hundred and three (203) copies of the questionnaire were retrieved which represents $96.6 \%$ percent of the entire population.

\subsection{Research Question 1}

How are employees' performances measured in the selected private secondary schools in Port Harcourt?

To answer the research question, the mean responses of the respondents to the second section of the questionnaire were calculated and the results are presented in Table 1 below:

Table 1. Mean responses on how employees' performances are measured in the selected private secondary schools in Port Harcourt

\begin{tabular}{|l|l|l|l|l|l|l|l|l|l|}
\hline S/N & $\begin{array}{l}\text { How } \\
\text { employees' } \\
\text { performance } \\
\text { measured in your } \\
\text { organization }\end{array}$ & $\begin{array}{l}\text { Strongly } \\
\text { Agree }\end{array}$ & Agree & Disagree & $\begin{array}{l}\text { Strongly } \\
\text { Disagree }\end{array}$ & Total & Mean & $\begin{array}{l}\text { Standard } \\
\text { Deviation }\end{array}$ & Remark \\
\hline 1 & $\begin{array}{l}\text { By the outcomes of } \\
\text { their effort }\end{array}$ & 105 & 76 & 13 & 9 & 203 & 3.36 & 0.79 & Agree \\
\hline 2 & $\begin{array}{l}\text { By the behavioral } \\
\text { characteristics that } \\
\text { led to the outcomes }\end{array}$ & 46 & 114 & 24 & 19 & 203 & 2.92 & 0.84 & Agree \\
\hline 3 & $\begin{array}{l}\text { By how long they } \\
\text { have been working } \\
\text { in the organization }\end{array}$ & 32 & 52 & 80 & 39 & 203 & 2.38 & 0.97 & Disagree \\
\hline 4 & $\begin{array}{l}\text { By how closely } \\
\text { related they are to } \\
\text { the management }\end{array}$ & 22 & 40 & 78 & 63 & 203 & 2.10 & 0.96 & Disagree \\
\hline & $\begin{array}{l}\text { By the connections } \\
\text { they have with top } \\
\text { management }\end{array}$ & 20 & 35 & 75 & 73 & 203 & 2.01 & 0.96 & Disagree \\
\hline
\end{tabular}

The Table above shows that the respondents agreed to statements 1 and 2 while they disagreed to items 3, 4 and 5. They agreed that workers are measured by the outcomes of their effort and behavioural characteristics. They disagreed that workers are measured by how long they have been working in the organization, by how closely related they are to the management and by the connections they have with top management.

\subsection{Research Question 2}

How obligatory do the selected private secondary schools in Port Harcourt consider their core competencies during performance appraisals and performance management? 


\section{Ml Macrothink}

Business Management and Strategy

ISSN 2157-6068

2018, Vol. 9, No. 1

To answer the research question, the mean responses of the respondents to the third section of the questionnaire were calculated and the results are presented in Table 2 below:

Table 2. Mean responses on how obligatory core competencies are considered during the performance management process in selected private schools in Port Harcourt

\begin{tabular}{|c|c|c|c|c|c|c|c|c|c|}
\hline $\mathrm{S} / \mathrm{N}$ & $\begin{array}{l}\text { How obligatory are the } \\
\text { following competencies } \\
\text { applied during performance } \\
\text { appraisals and performance } \\
\text { management in your } \\
\text { organization? }\end{array}$ & $\begin{array}{l}\text { Very } \\
\text { Obligatory }\end{array}$ & Obligatory & $\begin{array}{l}\text { Not Very } \\
\text { Obligatory }\end{array}$ & $\begin{array}{l}\text { Not } \\
\text { Obligatory }\end{array}$ & Total & Mean & $\begin{array}{l}\text { Standard } \\
\text { Deviation }\end{array}$ & Remark \\
\hline 1 & Team Spirit & 94 & 69 & 24 & 16 & 203 & 3.19 & 0.93 & $\begin{array}{l}\text { Very } \\
\text { Obligatory }\end{array}$ \\
\hline 2 & Communication Ability & 80 & 86 & 23 & 14 & 203 & 3.14 & 0.87 & $\begin{array}{l}\text { Very } \\
\text { Obligatory }\end{array}$ \\
\hline 3 & People Management & 72 & 78 & 31 & 22 & 203 & 2.99 & 0.97 & Obligatory \\
\hline 4 & Problem-solving Ability & 83 & 87 & 20 & 13 & 203 & 3.18 & 0.85 & $\begin{array}{l}\text { Very } \\
\text { Obligatory }\end{array}$ \\
\hline 5 & Technical Ability & 63 & 88 & 30 & 22 & 203 & 2.95 & 0.94 & Obligatory \\
\hline 6 & Decision Making & 58 & 92 & 35 & 18 & 203 & 2.94 & 0.9 & Obligatory \\
\hline 7 & $\begin{array}{l}\text { Planning and Organizing } \\
\text { Ability }\end{array}$ & 75 & 91 & 23 & 14 & 203 & 3.12 & 0.86 & $\begin{array}{l}\text { Very } \\
\text { Obligatory }\end{array}$ \\
\hline 8 & Result Orientation & 103 & 74 & 15 & 11 & 203 & 3.33 & 0.83 & $\begin{array}{l}\text { Very } \\
\text { Obligatory }\end{array}$ \\
\hline 9 & Leadership Ability & 71 & 87 & 31 & 14 & 203 & 3.06 & 0.88 & $\begin{array}{l}\text { Very } \\
\text { Obligatory }\end{array}$ \\
\hline 10 & student friendly & 77 & 73 & 31 & 22 & 203 & 3.01 & 0.98 & $\begin{array}{l}\text { Very } \\
\text { Obligatory }\end{array}$ \\
\hline 11 & Initiative & 57 & 107 & 29 & 10 & 203 & 3.04 & 0.79 & $\begin{array}{l}\text { Very } \\
\text { Obligatory }\end{array}$ \\
\hline 12 & Interpersonal skills & 66 & 95 & 31 & 11 & 203 & 3.06 & 0.83 & $\begin{array}{l}\text { Very } \\
\text { Obligatory }\end{array}$ \\
\hline
\end{tabular}

The results in Table 2 above show that the respondents rated item 1,2,4,7,8,9,10,11 and 12 as very obligatory. The competencies include Team Spirit, communication ability, problem-solving ability, planning and organizing ability, result orientation, leadership ability, student-friendly, initiative and interpersonal skills. The respondents also rated the item 3, 5 and 6 (which include People Management, Technical ability and Decision Making) as obligatory. 


\subsection{Hypothesis}

Male and female staff of the selected private secondary schools in Port Harcourt do not significantly differ in their mean ratings as to how obligatory their core competences are considered during performance management.

The hypothesis was tested using Z-test at 0.05 level of significance and the results are presented in Table 3.

Table 3. Z-test showing result on the difference in the mean ratings of male and female staff on how obligatory private secondary schools consider their core competences during performance management

\begin{tabular}{|l|l|l|}
\hline & FEMALE STAFF & MALE STAFF \\
\hline Mean & 3.246985294 & 3.226268657 \\
\hline Known Variance & 0.275 & 0.307 \\
\hline Observations & 136 & 67 \\
\hline Hypothesized Mean Difference & 0 & \\
\hline $\mathrm{Z}$ & 0.254924076 & \\
\hline $\mathrm{P}(\mathrm{Z}<=\mathrm{z})$ one-tail & 0.39939087 & \\
\hline $\mathrm{z}$ Critical one-tail & 1.644853627 & \\
\hline $\mathrm{P}(\mathrm{Z}<=\mathrm{z})$ two-tail & 0.798781741 & \\
\hline $\mathrm{z}$ Critical two-tail & 1.959963985 & \\
\hline
\end{tabular}

The results in the above table show that the Z-Calculated of 0.255 is less than the Z-Critical Value of 1.96 tested at 0.05 level of significance and at degree of freedom of 201. The hypothesis is therefore accepted which means that male and female staff of the selected secondary schools do not differ significantly in their mean ratings of how obligatory they consider the used of competencies in their performance management process

\subsection{Discussion of Findings}

The results in the Research Question 1 presented in Table 1, reveal that the respondents agree that employees' performances are measured by the outcomes of their effort (Mean of 3.09), and by the behavioural characteristics that led to the outcomes (mean of 2.92). However, the respondents disagreed that performances are measured by how long they have been working in the organization (mean of 2.38), by how closely related they are to the management (mean of 2.10), and by the connections they have with the top management (mean of 2.01). The results are in line with those of Asamu (2013) who pointed out that there is a significant relationship between workers performance and workers appraisal. Asamu also found out that there is a significant relationship between workers performance appraisal and employees commitment to the goals and objectives of the organization.

The result of research question 2, presented in Table 2, showed the competencies that were 
regarded as obligatory during the performance management process of private secondary schools in Port Harcourt. Team spirit, communication ability, problem-solving ability, planning and organizing ability, result orientation, leadership ability, student friendly, initiative, and interpersonal skills were rated as very obligatory. People management ability, technical ability and decision making ability were rated as obligatory. The results are in line with the report of Corporate Leadership Council (2004) that reported that seven core competencies were used in the perfomanance management process of the Minnesota Department of Transportation. These competencies were derived by integrating the organizations' mission, vission and values. The competencies focused on individual skills knowledge and behaviours rather than qualifications or experiences. Teaching and non-teaching staff of secondary schools ought to possess both behavioural and technical competencies which will aid them to attend to parents and students.

The result of the Hypothesis 1, presented in Table 3, reveals that there is is no significant difference in the responses of male and female staff on how obligatory their organizations consider their core competencies during performance management process. The hypothesis was accepted because the Z-Calculated (0.255) was lower than the Z-Critical value (1.959). This means that the male and female staff of the two selected secondary schools do not differ in their opinions on how obligatory the core competenicies of their organizations are employed during the performance management process.

\section{Conclusion}

From the findings of the study, it is clear that Private secondary schools in Port Harcourt do measure their employees' performance based on the outcomes of their effort and the behavioral characteristics that led to those outcomes. Also, the results show that the performance management process was not based on how long the employee has been in the organization or how closely related they are with the top management. The workers studied indicated that all the competencies listed were considered obligatory during the performance management process of their organizations.

\section{Recommendation}

Based on the findings of the study and the conclusions drawn, the researcher makes the following recommendations:

1. Management of private secondary schools in Port Harcourt should lay more emphasis on behavioral competences not just on only the outcome of employees' effort.

2. Human resources officers of private educational institutions in Port Harcourt should ensure that standard performance management procedures, devoid of sentiments and all forms of subjectivity, be set up in their organizations.

3. Private educational institutions in Port Harcourt need to emphasize more or technical skills during the performance management process. Teachers who did not read education should be given an ultimatum to upgrade themselves or else be relieved of their duties. 


\section{References}

Aguinis, H. (2011). Performance Management. Edinburgh: Edinburgh Business School.

Armstrong, M. (2006). A handbook of human resource management practice. 10th Edition. . London: Kogan page Ltd.

Asamu, F. F. (2013). Perception Of Performance Appraisal And Workers' Performance. Global Journal of Arts, Humanities and Social Sciences , 1(4), 89-101.

Boguslauskas, V., \& Kvedaraviciene, G. (2009). Difficulties in identifying company's core competencies and core processes. Inzinerine Eknonomika-Engineering Economics, (2), 75-81.

Boyatzis, R. (1982). The competent manager. New York: Wiley.

Cole, G. A. (2002). Personnel and human resource managment. Hampshire, UK: Cengage Learning.

Corporate Leadership Council. (2004, December 1). The Use of Competencies in Performance Management Programs. Retrieved from http://isites.harvard.edu/fs/docs/icb.topic608877.files/Class\%20Three\%20Reading/CLC_The _Use_of_Competencies_in_Performance_Management_Programs.pdf

Hayton, J. C., \& Kelley, D. J. (2006). A competency-based framework for promoting corporate entrepreneurship. . Human Resources Management, 45(3), 407-427. https://doi.org/10.1002/hrm.20118

Kogut, B., \& Kulatilaka, N. (2001). Capabilities as real optins. Organization Science, 744-758. http://dx.doi.org/10.1287/orsc.12.6.744.10082

Koloupolus, T. M., \& Rollof, T. (2006). Smartsourcing. Driving innovation and Growth through outsourcing. USA: Platinum Press.

Moore, G. (2002). Living on the Fault line. New York: HarperCollins Publishers.

Nwachukwu, C. C. (2009). Human Resources Management. Port Harcourt: Davidstones Publishers Ltd.

Rigby, D., \& Bilodeau, B. (2007, September 29). Management tools and trends 2007. Retrieved from Bain and Company. Retrieved from http://www.bain.com/offices/saopaulo/pt/Images/Management_Tools_2007_BB.pdf

Seo, B. D., Park, M. K., \& Lee, W. H. (2016). Developing a core competency model for Leaders in Industry-University Cooperation a K-University: A case study. International Journal of Software Engineering and Its Applications, 10(2), 171-180. https://doi.org/10.14257/ijseia.2016.10.2.14

Stoner, J. A. F., Freeman, R. E., \& Gilbert, D. R. (2008). Management $6^{\text {th }}$ Edition. New Delhi: 
PHI Learning Private Limited.

Sunil, J. R. (2006). Identifying and understanding HR competencies and their relationship to organizational practices. Applied Human Resources Management Research, 11(1), 27-38.

Takey, M. S., \& de Carvalho, M. M. (2015). Competency mapping in project management: An action research study in an engineering company. International Journal of Project Management, 33, 784-796. https://doi.org/10.1016/j.ijproman.2014.10.013

\section{Copyright}

Copyright for this article is retained by the author(s), with first publication rights granted to the journal.

This is an open-access article distributed under the terms and conditions of the Creative Commons Attribution license (http://creativecommons.org/licenses/by/4.0/). 